\title{
Preparation and Characterization of Polymer Electrolyte of Glycidyl Methacrylate-Methyl Methacrylate-LiClO Plasticized with Ethylene Carbonate
}

\author{
M. Imperiyka, ${ }^{1}$ A. Ahmad, ${ }^{1,2}$ S. A. Hanifah, ${ }^{1}$ and M. Y. A. Rahman ${ }^{3}$ \\ ${ }^{1}$ School of Chemical Sciences and Food Technology, Faculty of Science and Technology, Universiti Kebangsaan Malaysia, \\ 43600 Bangi, Selangor, Malaysia \\ ${ }^{2}$ Polymer Research Center, Faculty of Science and Technology, Universiti Kebangsaan Malaysia, 43600 Bangi, Selangor, Malaysia \\ ${ }^{3}$ Institute of Microengineering and Nanoelectronics (IMEN), Universiti Kebangsaan Malaysia, 43600 Bangi, Selangor, Malaysia
}

Correspondence should be addressed to A. Ahmad; azizan@ukm.edu.my and M. Y. A. Rahman; mohd.yusri@ukm.edu.my

Received 19 March 2014; Accepted 16 April 2014; Published 14 May 2014

Academic Editor: Yulin Deng

Copyright (C) 2014 M. Imperiyka et al. This is an open access article distributed under the Creative Commons Attribution License, which permits unrestricted use, distribution, and reproduction in any medium, provided the original work is properly cited.

\begin{abstract}
In the present investigation, we study the properties of the plasticized polyglycidyl methacrylate $\mathrm{P}(\mathrm{GMA})$ copolymerized with polymethyl methacrylate $\mathrm{P}(\mathrm{MMA})-\mathrm{LiClO}_{4}$ polymer electrolyte prepared by solution casting technique. The electrolyte was characterized using impedance spectroscopy (EIS), Fourier transforms infrared (FTIR), cyclic voltammetry (CV), and X-ray diffraction (XRD). The conductivity was improved from $1.3 \times 10^{-12} \mathrm{~S} \mathrm{~cm}^{-1}$ to $8.7 \times 10^{-6} \mathrm{~S} \mathrm{~cm}^{-1}$ upon the addition of $25 \mathrm{wt}^{2} \% \mathrm{LiClO}_{4}$ salt into P(GMA-MMA). The conductivity was improved from $1.4 \times 10^{-6} \mathrm{~S} \mathrm{~cm}^{-1}$ to $3.0 \times 10^{-4} \mathrm{~S} \mathrm{~cm}^{-1}$ upon the addition of 80 wt.\% EC into $\mathrm{P}(\mathrm{GMA}-\mathrm{MMA})-\mathrm{LiClO}_{4}$ The band that belongs to $\mathrm{C}-\mathrm{O}-\mathrm{C}$ is shifted farther than the band of $\mathrm{C}=\mathrm{O}$ upon the addition of $\mathrm{LiClO}_{4}$ into $\mathrm{P}(\mathrm{GMA}-\mathrm{MMA})$. The band of C-O-C stretching is shifted to lower wavenumber upon the addition of EC into $\mathrm{P}(\mathrm{GMA}$ MMA)- $\mathrm{LiClO}_{4}$. Upon the addition of EC into P(GMA-co-MMA), the intensity of the peaks decreases, implying the amorphous nature of the electrolyte increases with the concentration of the plasticizer. The electrolyte is electrochemically stable at $3.8 \mathrm{~V}$, making it suitable for dye-sensitized solar cell application.
\end{abstract}

\section{Introduction}

Dye-sensitized solar cells (DSSCs) have received considerable attention due to low manufacturing cost and simple preparation technique over conventional solar cells. Dyesensitized solar cells (DSSCs) are considered as third generation photovoltaic devices that combine high-energy conversion efficiency together with low production cost. The most important issue of the dye-sensitized cells is the stability over the time and the temperature range which occurs under outdoor conditions. A photoelectric conversion efficiency of $12.5 \%$ has been obtained in DSSCs with organic solvent-based electrolyte [1]. Even though the high conversion efficiencies were obtained for the dye-sensitized solar cells with liquid electrolytes, potential problems caused by liquid electrolytes, such as leakage and volatilization of the liquid and possible corrosion of the counter electrode, have brought about difficulties in cell fabrication limiting the long-term performance and practical use of these dye-sensitized solar cells [2]. Several methods have been introduced to prevent electrolyte leakage. One of the strategies is to replace the volatile solvents with ionic liquids [3]. Secondly, P-type semiconductors [4], inorganic hole transport materials [5], organic hole transport materials [6], and finally polymer/redox couples blends [7] have been introduced as substitutions for traditional liquid electrolyte in all solid-state photoelectrochemical cell configurations. Nanocomposite polymer electrolyte $[8,9]$, polymer gel $[10,11]$, and solid state or quasi-solid state polymer materials $[12,13]$ have been utilized to replace the organic liquid electrolyte in DSSC. Replacing liquid electrolytes with solid electrolytes, the solvent-free polymer electrolytes are materials of immediate interest. The efficient DSSCs using 
methacrylate compound-based solid polymer electrolytes were showing advantageous properties and sufficient efficiency [14].

The main problem associated with P(GMA-co-MMA) is its low ionic conductivity at room temperature. Adding plasticizers is a known unique approach to enhance the ionic conductivity. Nowadays, many advantageous properties of solid polymer (SPEs) based electrolytes like preventing electrolyte leakage and liquid evaporation make them suitable electrolyte for DSSCs [10]. Here, we have introduced one approach to modify polymer electrolyte system and achieve high ionic conductivity which is desirable for DSSC application. We have added plasticizer ethylene carbonate (EC) into P(GMA-co-MMA) matrix to enhance the flexibility of polymer chains and consequently improved the ionic conductivity.

\section{Materials and Methods}

2.1. Materials. Glycidyl methacrylate (GMA), methyl methacrylate (MMA), 2,2-dimethoxy-2-phenylacetophenone (DMPP), and lithium perchlorate $\left(\mathrm{LiClO}_{4}\right)$ were purchased from Aldrich. Tetrahydrofuran (THF) was obtained from J.T. Baker. Ethylene carbonate (EC) and acetonitrile were supplied from Fluka and Dyesol, respectively.

\subsection{Preparation of UV-Cured Polymer and UV-Cured Polymer} Electrolyte. Copolymer was prepared by photopolymerization technique in the presence of DMPP as photoinitiator as reported in our previous work [29]. Polymer electrolyte samples containing different amounts of lithium salts were prepared by solution casting method. Tetrahydrofuran (THF) was used as a solvent. The mixture of polymer, lithium salts, and solvent was mixed and stirred for $24 \mathrm{hrs}$ until a homogeneous solution was obtained. Then, the solutions were poured into Teflon mold and left to dry at ambient temperature until electrolyte films were formed. Finally, the electrolyte films of $\mathrm{P}(\mathrm{GMA}-\mathrm{MMA})-\mathrm{LiClO}_{4}$ were dried in a vacuum oven at $40^{\circ} \mathrm{C}$ for $2 \mathrm{hrs}$ and kept inside a desiccator for their characterization and testing. Polymer electrolyte homogeneous solutions of P(GMA-co-MMA) with different concentration of lithium salts have been prepared in order to investigate the highest ionic conductivity of the electrolyte system. Then, the films of plasticized polymer electrolytes with a general formula of P(GMA-co-MMA)-30 wt. $\% \mathrm{LiClO}_{4}-x$ wt.\% EC $(x=20$, 40,60 , and 80 ) have been prepared via solution casting technique. Three grams of copolymer was added into $30 \mathrm{~mL}$ tetrahydrofuran (THF) and stirred using a magnetic stirrer. The $\mathrm{LiClO}_{4}$ was then added into different content of EC. The two separate solutions were mixed and further stirred for $24 \mathrm{hrs}$. The homogeneous solution was then poured onto Teflon mould and the solvent was then slowly removed by locating the mould in fume hood. The electrolyte films of $\mathrm{P}(\mathrm{GMA}-\mathrm{MMA})$-EC- $\mathrm{LiClO}_{4}$ were dried in a vacuum oven at $40^{\circ} \mathrm{C}$ for $48 \mathrm{hrs}$ in order to remove the residual solvent. The free standing films were peeled from the Teflon plates and stored in a dry box. Figure 1 illustrates the highly translucent nature of $\mathrm{P}\left(\mathrm{GMA}\right.$-co-MMA)- $\mathrm{LiClO}_{4}$-EC. The electrolyte film is transparent.

2.3. Characterization of UV-Cured Solid Polymer Electrolyte. On the other hand, to measure the impedance of the electrolyte films, the samples were cut into round shapes of $16 \mathrm{~mm}$ in diameter to fit in with the size of electrodes. The samples were then sandwiched between stainless steel electrodes which have a surface contact area of $2.0 \mathrm{~cm}^{2}$ and these were then mounted onto the sample holder. The conductivity was then determined by impedance spectroscopy under condition of $1 \mathrm{MHz}$ to $10 \mathrm{~Hz}$. The bulk resistance $\left(R_{b}\right)$ of the electrolyte was determined from the interception of the real impedance axis ( $z$-axis) by using $Z$-View software. The thickness of the film was determined by using a micrometer. The conductivity was calculated using the formula $\sigma=$ $l / R_{b} A$, where $l$ is the film thickness $(\mathrm{cm})$ and $A\left(\mathrm{~cm}^{2}\right)$ is the effective contact area of the electrolyte and electrode. Fourier transforms infrared (ATR-FTIR) test was conducted using Perkin-Elmer spotlight 400 imaging system in the frequency range 3100 to $800 \mathrm{~cm}^{-1}$. FTIR was performed to identify the type of bonding of copolymer with ion pairs of complexation samples at room temperature. The electrochemical stability of the electrolyte was obtained from -5 to $+5 \mathrm{~V}$ at a scanning rate of $50 \mathrm{mV} \mathrm{s}^{-1}$ by using a two- (stainless steel-) electrode cell at room temperature. The X-ray diffraction (XRD) D-5000 Siemens diffractometer technique was performed to study the crystallinity and the phase structure of the polymer electrolytes.

\section{Result and Discussion}

3.1. Ionic Conductivity. The variation of conductivity of copolymer based polymer electrolyte as a function of the lithium salt concentration is presented in Figure 2. The ionic conductivity of polymer electrolyte was enhanced with the addition of salt and the conductivity attains a maximum value when the $\mathrm{LiClO}_{4}$ concentration reached $25 \mathrm{wt} . \%$. The ionic conductivity of polymer electrolyte was found to be further enhanced to maximum conductivity of $8.7 \times 10^{-6} \mathrm{~S} \mathrm{~cm}^{-1}$. The addition of $\mathrm{LiClO}_{4}$ in the polymer matrix tends to increase the order in amorphous state and results in higher ionic conductivity as a result of the strong interaction between polymer and $\mathrm{LiClO}_{4}$. However, when the lithium salt concentration reaches certain value, the excess dissociated $\mathrm{Li}^{+}$ and $\mathrm{ClO}_{4}{ }^{-}$ions may form ion pairs or ion clusters, which reduces the free ions concentration and leads to the decrease of the conductivity $[15,16]$. The mechanical property of the electrolyte film over $35 \%$ salt is not free standing, not flexible, sticky, and gelly. Moreover, the salt cannot be added into $\mathrm{P}$ (GMA-MMA)-EC anymore since it is overloaded. That is why we stopped at $35 \mathrm{wt}$. \% $\mathrm{LiClO} 4$ while preparing the electrolyte.

The $\mathrm{P}$ (GMA-co-MMA) with $\mathrm{LiClO}_{4}$ based polymer electrolyte with optimum ionic conductivity was mixed as function of concentration of EC. Figure 3 shows the ionic conductivity of $\mathrm{P}$ (GMA-co-MMA)-25 wt. $\% \mathrm{LiClO}_{4}$ with various EC content at room temperature. As can be seen from 


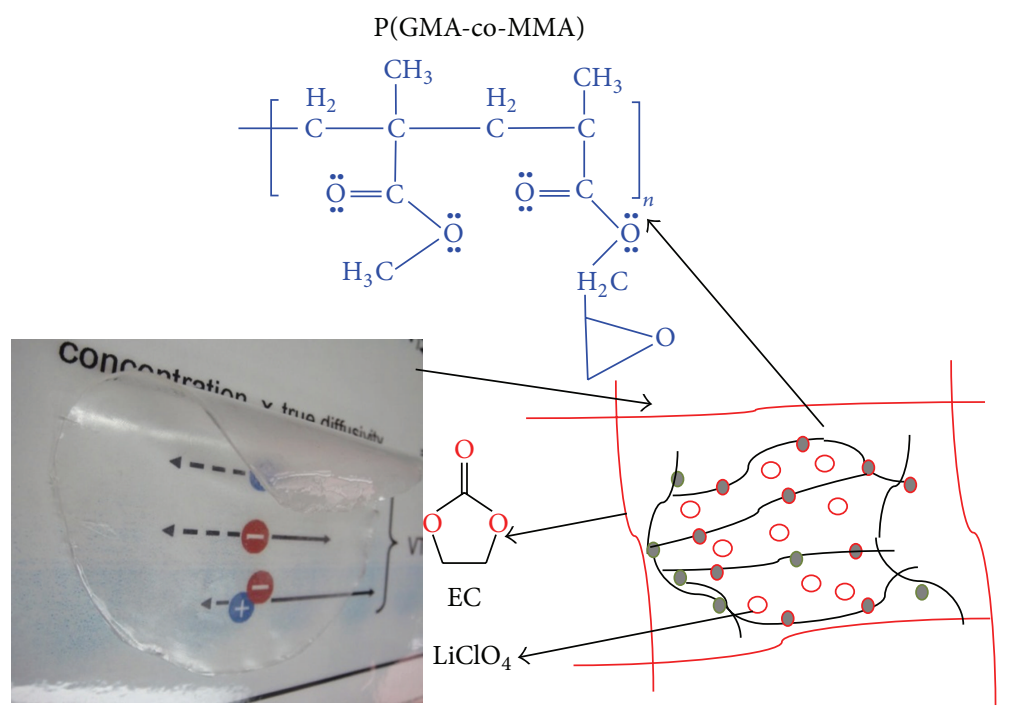

Figure 1: Appearance of P(GMA-co-MMA)-LiClO ${ }_{4}$-EC.

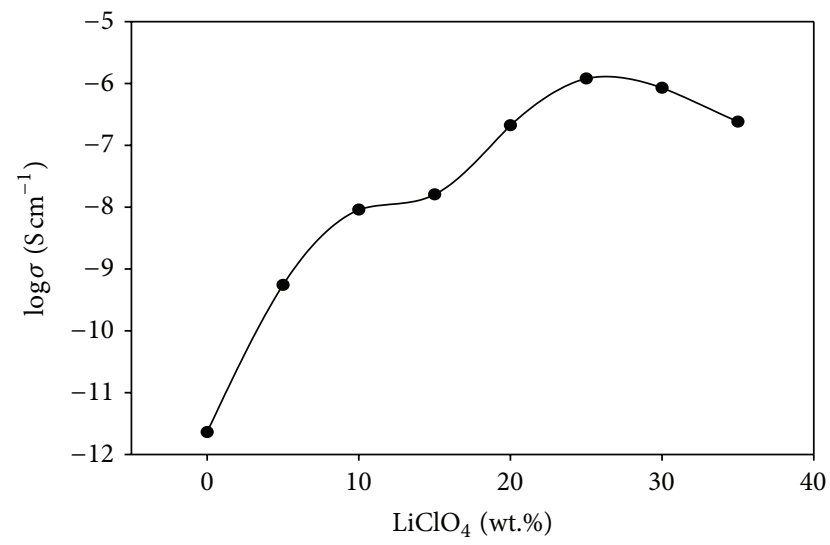

FIGURE 2: Ionic conductivity of $\mathrm{P}(\mathrm{GMA}-\mathrm{co}-\mathrm{MMA})-\mathrm{LiClO}_{4}$ based polymer electrolyte as a function of $\mathrm{LiClO}_{4}$ content.

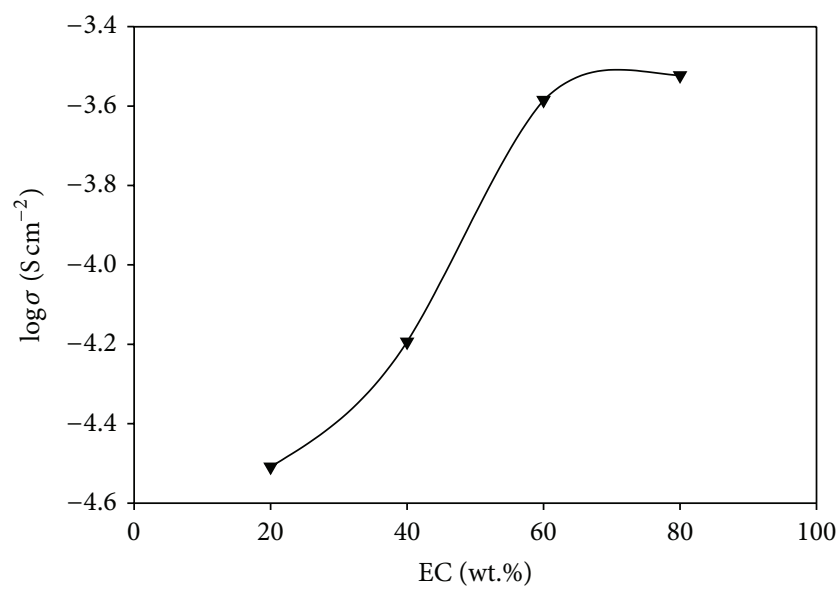

FIGURE 3: Variation of ionic conductivity of P(GMA-co-MMA)-EC$\mathrm{LiClO}_{4}$ based polymer electrolyte as a function of EC content.
Figure 3, the conductivity increases with the addition of EC content. The film with the composition higher than 80 wt.\% EC was mechanically unstable; hence the conductivity was difficult to measure. The conductivity increases slowly from $1.4 \times 10^{-6} \mathrm{~S} \mathrm{~cm}^{-1}$ to $3.0 \times 10^{-4} \mathrm{~S} \mathrm{~cm}^{-1}$ for P(GMAco-MMA)-25 wt. $\% \mathrm{LiClO}_{4}-80$ wt. $\%$ EC. This conductivity is higher than that of $\mathrm{P}(\mathrm{GMA}-\mathrm{CO}-\mathrm{MMA})$ reported in [17] for which the conductivity of $2.7 \times 10^{-5} \mathrm{~S} \mathrm{~cm}^{-1}$ was achieved at $30 \mathrm{wt} . \% \mathrm{LiClO}_{4}$. Generally, the enhancement of ionic conductivity in plasticized solid polymer electrolyte can be explained by the interaction between polymer $\mathrm{LiClO}_{4}$ and EC. There are three main interactions among them (i) ionion interaction between $\mathrm{Li}^{+}$cations and $\mathrm{ClO}_{4}{ }^{-}$anions, (ii) ion-dipole interactions between $\mathrm{Li}^{+}$cations and chlorine in polymer, and (iii) ion-molecule interactions between $\mathrm{Li}^{+}$and EC [18]. These interactions are important to form polymer$\mathrm{LiClO}_{4}$-EC polymer electrolyte, in which three different compounds of polymer- $\mathrm{Li}^{+}$, polymer- $\mathrm{Li}^{+}-\mathrm{EC}$, and $\mathrm{Li}^{+}-\mathrm{EC}$ exist. The oxygen of $\mathrm{C}=\mathrm{O}$ in $\mathrm{EC}$ is an electron donor which participates in competition with $\mathrm{ClO}_{4}{ }^{-}$and polymer. The $\mathrm{Li}^{+}$-EC interactions exist not only between $\mathrm{Li}^{+}$and oxygen atoms of $\mathrm{C}=\mathrm{O}$ group, but also between $\mathrm{Li}^{+}$and another two oxygen atoms in the ring structure of EC. Besides that, $\mathrm{Li}^{+}$EC interaction plays an important role in the conductivity of polymer- $\mathrm{LiClO}_{4}$-EC system. The addition of EC leads to the formation of $\mathrm{Li}^{+}$-EC complex and enhances the flexibility of polymer chains by decreasing the crystalline fraction of polymer- $\mathrm{Li}^{+}$complex. The high dielectric constant of EC $\left(\varepsilon_{r}=85.1\right)$ effectively reduces the inter-ion coulomb interactions; hence, more $\mathrm{Li}^{+}$contributed to the conductivity of the complexes [19-21]. Furthermore, EC molecules are relatively small in size compared to polymer host molecule and therefore can easily transfuse into the polymer matrix, causing an interaction between plasticizer molecule and polymer chain molecules. This reduces the cohesive forces operating between the polymer chains resulting in an increase in the 
chain segmental mobility [18]. The increase in chain segmental mobility facilities ion transport leads to enhancement of conductivity. The conductivity decreases at $70 \mathrm{wt} . \% \mathrm{EC}$ since it is a saturated level for EC addition into P(GMA-co-MMA)$\mathrm{LiClO}_{4}$. This results in less space for $\mathrm{Li}^{+}$ions to move within the matrix of $\mathrm{P}(\mathrm{GMA}-\mathrm{Co}-\mathrm{MMA})-\mathrm{EC}$.

3.2. Fourier Transforms Infrared (FTIR). The FTIR spectra of the polymer system change according to their composition and may be able to show the occurrence of complexation and interaction between the various constituents. The possible mechanism of dissociation of lithium salt and plasticizer in polymer host has been proposed in [22] as shown in Figure 4. EC can introduce a new ionic pathway along which the $\mathrm{Li}^{+}$ ions can hop through the polymer.

Figures 5, 6, and 7 show the FTIR spectra of P(GMAco-MMA)-25 wt.\% $\mathrm{LiClO}_{4}$ with varying percentage of EC plasticizer. If the shift in peak is above $1 \mathrm{~cm}^{-1}$, it is considered significant. $1 \mathrm{~cm}^{-1}$ difference is the uncertainty of the FTIR spectrum. The identified peaks of polymer electrolyte complex and their changes are listed in Table 1. From Figure 5, the $\mathrm{C}=\mathrm{O}$ stretching of $\mathrm{EC}$ is not observed in the spectrum of the EC free sample. With the addition of $20 \mathrm{wt} . \%$ EC into the system, $\mathrm{C}=\mathrm{O}$ a doublet peak was observed at 1802 and $1773 \mathrm{~cm}^{-1}$. The doublet peaks shift to lower wavenumbers at the addition of 40 wt.\% EC. Further addition of 80 and 80 wt.\% EC has shifted the doublet peaks to even lower wavenumber at 1801 and $1772 \mathrm{~cm}^{-1}$. The shift phenomena are due to the interaction between the $\mathrm{Li}^{+}$ions from $\mathrm{LiClO}_{4}$ and the oxygen atoms of the ring group of EC including the $\mathrm{C}=\mathrm{O}$ band [23]. In [24], the shift of the $\mathrm{C}=\mathrm{O}$ bending in pure EC was reported due to the interaction between $\mathrm{Li}^{+}$ salt and $\mathrm{C}=\mathrm{O}$ group of the $\mathrm{EC}$ molecules and their results are in a good agreement with those reported in $[25,26]$. However, there are no significant changes in the $\mathrm{C}=\mathrm{O}$ peak of the polymer host. According to the result reported in [18], there was only physical interaction that appeared among EC, polymer host, and salt. The interaction of $\mathrm{Li}^{+}$and $\mathrm{O}=\mathrm{C}$ of coordination GMA competes with $\mathrm{Li}^{+}$and $\mathrm{O}=\mathrm{C}$ of EC in plasticized samples. This is because $\mathrm{P}(\mathrm{GMA}-\mathrm{co}-\mathrm{MMA})$ has a larger molecule size in comparison to EC molecule; hence, the interaction between (GMA-co-MMA) and lithium salt was stronger as compared to EC-lithium salt.

After the addition of EC, the band for $\mathrm{C}-\mathrm{O}-\mathrm{C}$ stretching of film was found to shift from 1252 to $1249 \mathrm{~cm}^{-1}$, and the bands of these group peaks disappear as shown in Figure 7. The $\mathrm{C}=\mathrm{O}$ bending band belonging to $\mathrm{EC}$ is observed in FTIR spectrum after the addition of EC into system. This is assigned to the interaction between $\mathrm{Li}^{+}$of the salt after the addition of EC into the system. This result is in good agreement with the one that has been reported in [25]. Due to the increase in amount of EC, the physical interaction between EC, polymer, and salt was established, as the signal around 906 and $850 \mathrm{~cm}^{-1}$ which belong to epoxy group shifted to 803 and $896 \mathrm{~cm}^{-1}$ and enhanced lithium ion mobility. An interaction between salt and plasticizer leads to reduction in the coulombic interaction between the cation and anion of salt thus dissociating the salt to produce more mobile ions.

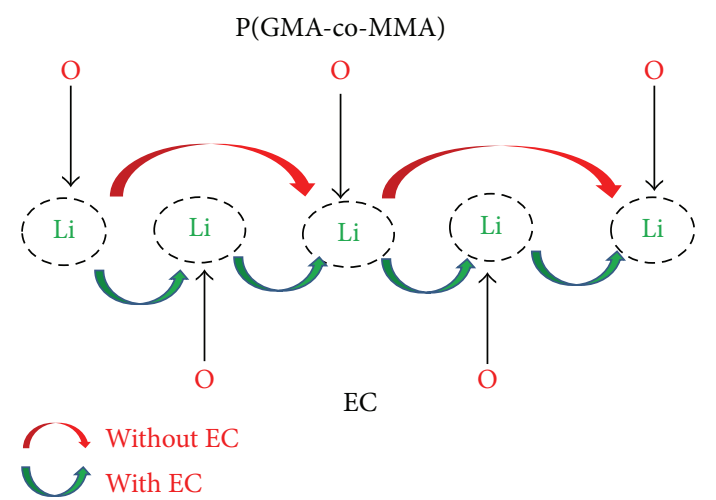

FIgURE 4: Possible conductivity mechanism of polymer based polymer electrolyte with EC.

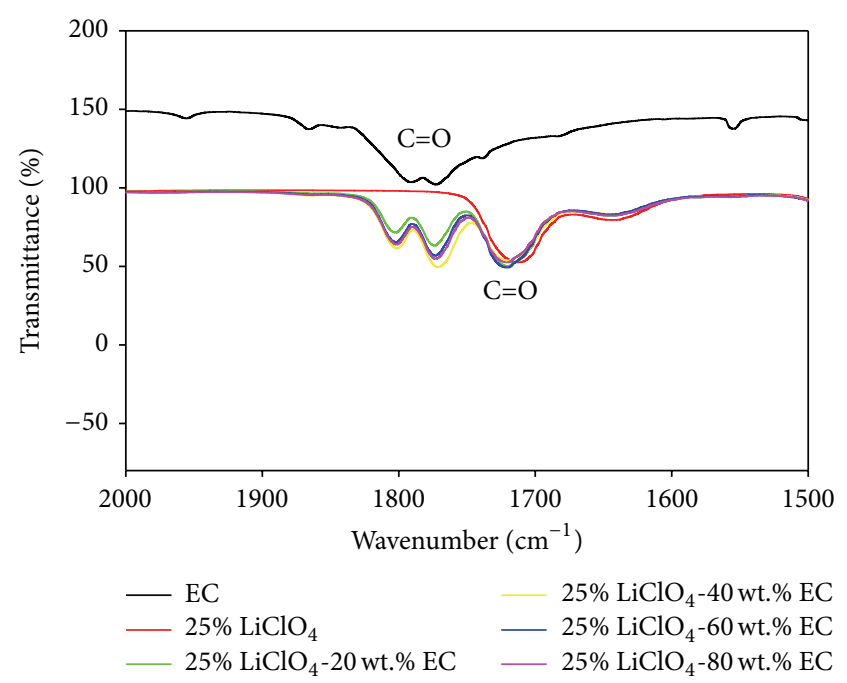

Figure 5: FTIR spectra of PGMA-25 wt.\% $\mathrm{LiClO}_{4}$-EC based polymer electrolyte as a function of $\mathrm{EC}$ in the wavenumber region 2000-1500 $\mathrm{cm}^{-1}$.

The interaction between plasticizer and salt may reduce saltpolymer interaction, which could increase chain flexibility [27]. This interaction is expected to occur between the $\mathrm{Li}^{+}$ ions with the oxygen atoms on $\mathrm{C}-\mathrm{O}-\mathrm{C}$ and $\mathrm{C}=\mathrm{O}$ in the $\mathrm{EC}$ ring structure as proposed in [19]. However, $\mathrm{Li}^{+}$ions prefer $\mathrm{C}-\mathrm{O}$ rather than $\mathrm{C}=\mathrm{O}$ [28]. It can be seen from Table 1 the band belonging to $\mathrm{C}-\mathrm{O}-\mathrm{C}$ is shifted farther than $\mathrm{C}=\mathrm{O}$ upon the addition of salt. However, these changes in peak intensity and shape revealed that complexation exists between lithium salt and oxygen atoms in the polymer host.

3.3. X-Ray Diffraction (XRD). Figure 8 shows the XRD patterns of $\mathrm{P}$ (GMA-co-MMA)-25 wt.\% $\mathrm{LiClO}_{4}$ complexed with various $\mathrm{EC}$ contents. This figure displays three humps in the region between $10^{\circ}-25^{\circ}, 25^{\circ}-35^{\circ}$ and $35^{\circ}-40^{\circ}$ in the spectra which could be attributed to the amorphous nature of $\mathrm{P}$ (GMA-co-MMA). The peaks pertaining to $\mathrm{LiClO}_{4}[29]$ are 
TABLE 1: Vibrational mode assignments of $\mathrm{P}(\mathrm{GMA}-\mathrm{co}-\mathrm{MMA})-25 \% \mathrm{LiClO}_{4}$ based polymer electrolyte with different percentage of EC.

\begin{tabular}{|c|c|c|c|c|c|}
\hline \multirow{2}{*}{ Vibrational mode of P(GMA-co-MMA) } & \multicolumn{4}{|c|}{ Wavenumber $\left(\mathrm{cm}^{-1}\right)$} & \multirow[b]{2}{*}{$80 \%$} \\
\hline & 0 & $20 \%$ & $40 \%$ & $60 \%$ & \\
\hline $\mathrm{C}=\mathrm{O}$ stretching of $\mathrm{EC}$ & - & 1802,1773 & 1801,1771 & 1802,1773 & 1801,1772 \\
\hline Carbonyl group stretching & 1712 & 1719 & 1719 & 1720 & 1720 \\
\hline Symmetric stretching of epoxy and ester group & $1252,1068,850$ & $1253,1071,566$ & $1246,1071,875$ & $1252,1071,890$ & $1249,1071,896$ \\
\hline Stretching $\mathrm{C}-\mathrm{O}-\mathrm{O}$ of ester group & 1154 & 1153 & 1157 & 1153 & 1154 \\
\hline Asymmetric stretching of epoxy & 906 & 903 & 901 & 902 & 903 \\
\hline $\mathrm{C}-\mathrm{H}$ blending vibration of epoxide ring & 748 & 749 & 748 & 749 & 748 \\
\hline $\mathrm{C}=\mathrm{O}$ bending & - & 718 & 718 & 718 & 718 \\
\hline
\end{tabular}

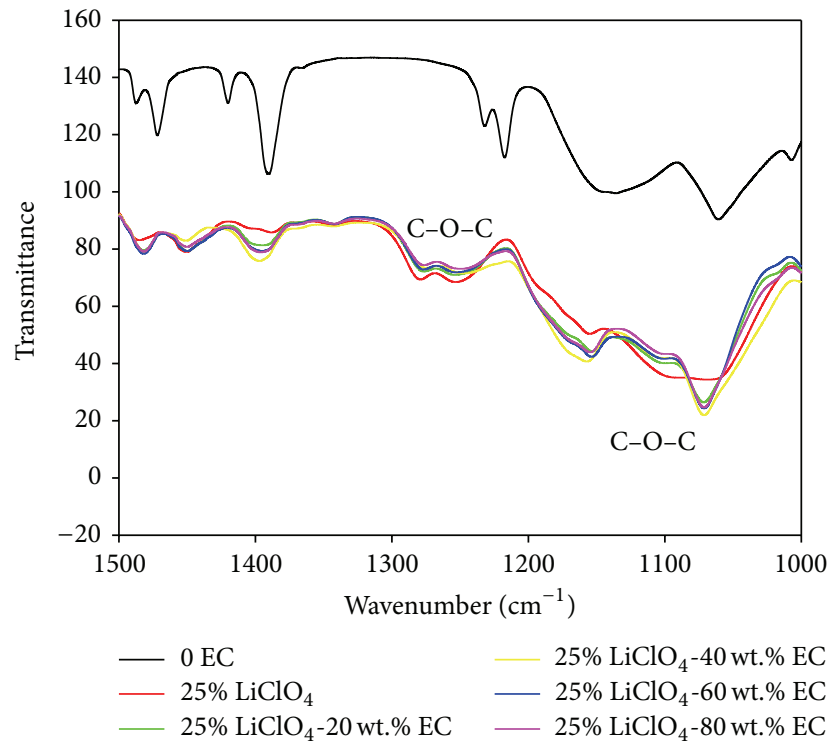

Figure 6: FTIR spectra of PGMA-25 wt.\% $\mathrm{LiClO}_{4}$-EC based polymer electrolyte as a function of $\mathrm{EC}$ in the wavenumber region $1500-1000 \mathrm{~cm}^{-1}$.

absent in the complexes. This indicates complete dissolution of the salt in the polymer matrices. These observations are similar to the work reported in [30] However, upon the addition of EC into P(GMA-Co-MMA), the intensity of the peaks decreases and a noticeable broadening of the area under the peaks is observed. This implies that the amorphous nature of the film increases with concentration of the plasticizer. The increase in the amorphous nature causes a reduction in the energy barrier to the segmental motion of the polymer electrolyte. The increase of amorphous area will improve ionic mobility and thus enhance the ionic conductivity of polymer electrolyte at room temperature. Similar findings were reported in $[31,32]$. Higher degree of amorphous phase was observed in host polymers- $\mathrm{LiClO}_{4}$ with $80 \mathrm{wt}$ \% $\mathrm{EC}$ in the total plasticizer content; hence ionic conductivity at this particular ratio was the highest. In [33], it was reported that the incorporation of polar carbonate groups into a polymer chain did not only reduce the crystallinity of the polymer, but also increased the dielectric constant relative to polymer with the same molecular weight, thereby providing the high flexibility necessary to promote ion mobility. The amorphous

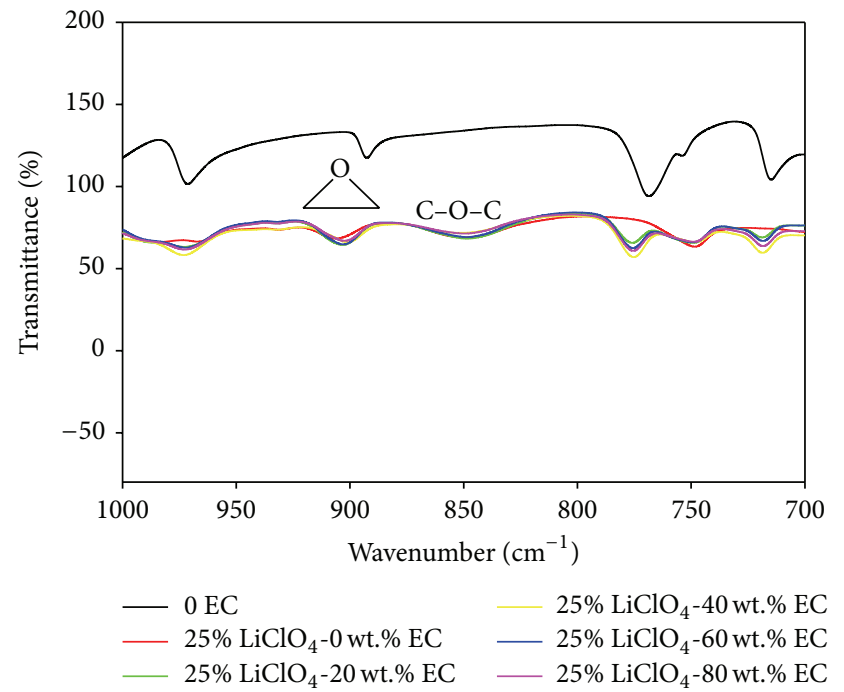

FIgURE 7: FTIR spectra of PGMA-25 wt.\% $\mathrm{LiClO}_{4}$-EC based polymer electrolyte as a function of $\mathrm{EC}$ in the wavenumber region $1000-700 \mathrm{~cm}^{-1}$.

nature produces greater ionic diffusivity leading to high ionic conductivity.

3.4. Cyclic Voltammetry (CV). Polymer electrolytes intended for practical applications in commercial devices must supply high lithium ion mobility to provide elevated power densities in device. Moreover, electrolytes must also be chemically stable to enable devices to attain extensive shelf lives in high voltage devices and they must be able to withstand the range of potential of the electrode couple. Figure 9 presents the cyclic voltammetry curves of $\mathrm{P}(\mathrm{GMA}-\mathrm{co}-\mathrm{MMA})-\mathrm{LiClO}_{4}$ with various EC contents. The stability of the polymer complexes at interface with stainless steel (SS) as electrode is limited by the potentials of $+3.8 \mathrm{~V}$ at anodic side and of $-3.8 \mathrm{~V}$ at the cathode side for P(GMA-co-MMA)-25 wt.\% $\mathrm{LiClO}_{4}$ EC. This could be due to noninteraction of the lithium ions in the polymer electrolyte with the SS electrodes. The cathodic peak at about $3.8 \mathrm{~V}$ has been attributed to the reduction of polymer complex. The oxidation degradation of polymer electrolyte on cathode is the key reason for safety problem of lithium ion battery, which can be understood by their electrochemical stability on stainless steel electrode [34]. Polymer 


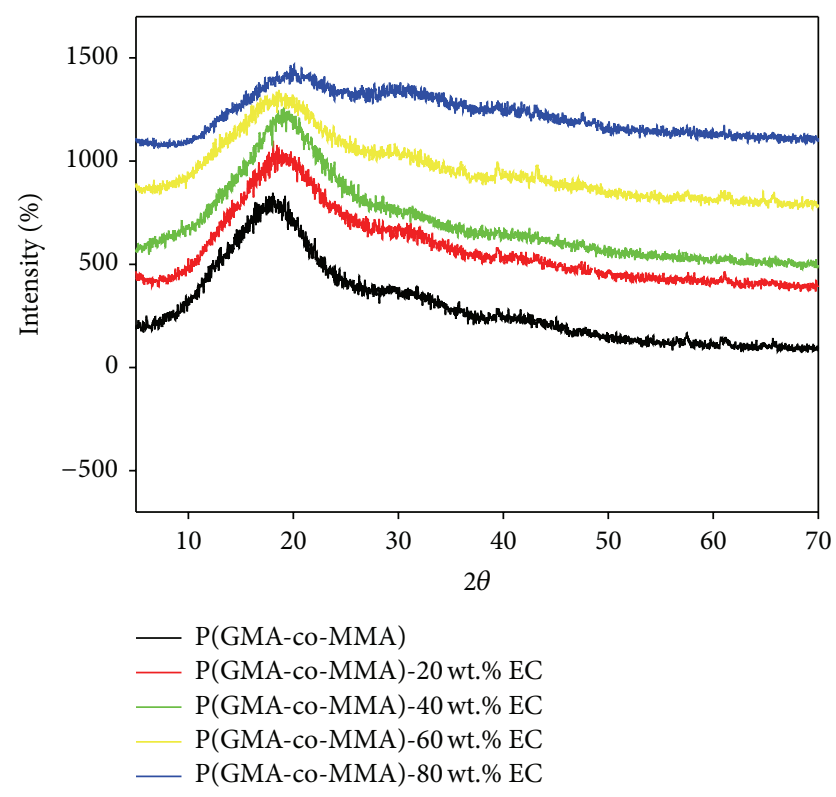

Figure 8: XRD patterns of P(GMA-co-MMA) 25 wt.\% $\mathrm{LiClO}_{4}$ as a function of EC content.

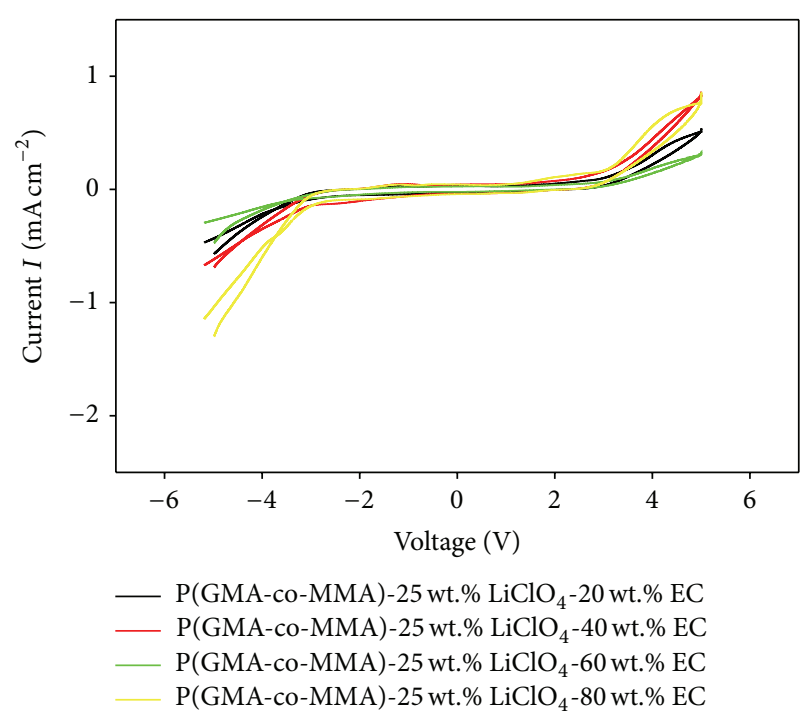

FIgUre 9: CV curves of P(GMA-co-MMA)-25 wt.\% $\mathrm{LiClO}_{4}$ based polymer electrolyte as a function of EC content.

electrolytes with plasticizer show higher electrochemical stability compared to polymer electrolyte without EC. However, the current density of electrolyte after breakdown potential is still low at low concentration of EC and it increases with EC concentration. In all polymer electrolytes, the current densities increase with increasing amount of EC. On the other hand, the electrochemical stability of polymer electrolytes is slightly affected by plasticizer concentration. The anodic stability is usually limited by the decomposition of polymer and lithium salt. In contrast, the situation with cathodic stability is more complicated as reported in [35]. Based on the obtained result, there is no oxidation peak related to the decomposition of polymer electrolytes in the scanning range, indicating that the electrolytes are suitable enough for the application.

\section{Conclusions}

We have prepared the plasticized polyglycidyl methacrylate $\mathrm{P}(\mathrm{GMA})$ copolymerized with polymethyl methacrylate $\mathrm{P}(\mathrm{MMA})-\mathrm{LiClO}_{4}$ polymer electrolyte via solution casting technique. The conductivity was improved about six orders upon the addition of $\mathrm{LiClO} 4$ salt into the $\mathrm{P}(\mathrm{GMA}-\mathrm{MMA})$ and about two orders upon the addition of EC to the P(GMAMMA)- $\mathrm{LiClO}_{4}$. Upon the addition of $\mathrm{LiClO}_{4}$ salt, the band belonging to $\mathrm{C}-\mathrm{O}-\mathrm{C}$ is shifted farther than $\mathrm{C}=\mathrm{O}$. Upon the addition of EC, the band for $\mathrm{C}-\mathrm{O}-\mathrm{C}$ stretching is shifted to lower wavenumber. Upon the addition of EC into P(GMAco-MMA)- $\mathrm{LiClO}_{4}$, the crystallinity degree of the electrolyte increases. The cyclic voltammetry analysis reveals that the electrolyte is suitable for dye-sensitized solar cell application.

\section{Conflict of Interests}

The authors declare that there is no conflict of interests regarding the publication of this paper.

\section{References}

[1] A. Yella, H.-W. Lee, H. N. Tsao et al., "Porphyrin-sensitized solar cells with cobalt (II/III)-based redox electrolyte exceed 12 percent efficiency," Science, vol. 334, no. 6056, pp. 629-634, 2011.

[2] A. F. Nogueira, M.-A. de Paoli, I. Montanari, R. Monkhouse, J. Nelson, and J. R. Durrant, "Electron transfer dynamics in dye sensitized nanocrystalline solar cells using a polymer electrolyte," Journal of Physical Chemistry B, vol. 105, no. 31, pp. 7517-7524, 2001.

[3] D. Kuang, C. Klein, Z. Zhang et al., "Stable, high-efficiency ionic-liquid-based mesoscopic dye-sensitized solar cells," Small, vol. 3, no. 12, pp. 2094-2102, 2007.

[4] S. Murai, S. Mikoshiba, H. Sumino, T. Kato, and S. Hayase, "Quasi-solid dye sensitised solar cells filled with phaseseparated chemically cross-linked ionic gels," Chemical Communications, vol. 9, no. 13, pp. 1534-1535, 2003.

[5] B. O’Regan, F. Lenzmann, R. Muis, and J. Wienke, "A solid-state dye-sensitized solar cell fabricated with pressure-treated P25$\mathrm{TiO}_{2}$ and CuSCN: analysis of pore filling and IV characteristics," Chemistry of Materials, vol. 14, no. 12, pp. 5023-5029, 2002.

[6] N. Ikeda, K. Teshima, and T. Miyasaka, "Conductive polymercarbon-imidazolium composite: a simple means for constructing solid-state dye-sensitized solar cells," Chemical Communications, no. 16, pp. 1733-1735, 2006.

[7] H. W. Han, W. Liu, J. Zhang, and X.-Z. Zhao, "A hybrid poly(ethylene oxide)/poly(vinylidene fluoride) $/ \mathrm{TiO}_{2}$ nanoparticle solid-state redox electrolyte for dye-sensitized nanocrystalline solar cells," Advanced Functional Materials, vol. 15, no. 12, pp. 1940-1944, 2005.

[8] M. Kaneko and T. Hoshi, "Dye-sensitized solar cell with polysaccharide solid electrolyte," Chemistry Letters, vol. 32, no. 9, pp. 872-873, 2003.

[9] T. Stergiopoulos, I. M. Arabatzis, G. Katsaros, and P. Falaras, "Binary polyethylene oxide/titania solid-State redox electrolyte 
for highly efficient nanocrystalline $\mathrm{TiO}_{2}$ photoelectrochemical cells," Nano Letters, vol. 2, no. 11, pp. 1259-1261, 2002.

[10] F. J. Li, F. Y. Cheng, J. F. Shi, F. S. Cai, M. Liang, and J. Chen, "Novel quasi-solid electrolyte for dye-sensitized solar cells," Journal of Power Sources, vol. 165, no. 2, pp. 911-915, 2007.

[11] M.-S. Kang, K.-S. Ahn, and J.-W. Lee, "Quasi-solid-state dyesensitized solar cells employing ternary component polymergel electrolytes," Journal of Power Sources, vol. 180, no. 2, pp. 896-901, 2008.

[12] J. Krüger, R. Plass, L. Cevey, M. Piccirelli, and M. Grätzel, "High efficiency solid-state photovoltaic device due to inhibition of interface charge recombination," Applied Physics Letters, vol. 79, no. 13, pp. 2085-2087, 2001.

[13] E. Stathatos, P. Lianos, S. M. Zakeeruddin, P. Liska, and M. Grätzel, "A quasi-solid-state dye-sensitized solar cell based on a sol-gel nanocomposite electrolyte containing ionic liquid," Chemistry of Materials, vol. 15, no. 9, pp. 1825-1829, 2003.

[14] F. Bella, D. Pugliese, J. R. Nair et al., "A UV-crosslinked polymer electrolyte membrane for quasi-solid dye-sensitized solar cells with excellent efficiency and durability," Physical Chemistry Chemical Physics, vol. 15, no. 11, pp. 3706-3711, 2013.

[15] F. Cai, X. Zuo, X. Liu, L. Wang, W. Zhai, and H. Yang, "The study of novel gel polymer electrolytes plasticized with non-volatile tris(methoxypolyethyleneglycol) aluminate esters," Electrochimica Acta, vol. 106, pp. 209-214, 2013.

[16] S. Rajendran, M. R. Prabhu, and M. U. Rani, "Ionic conduction in poly(vinyl chloride)/poly(ethyl methacrylate)-based polymer blend electrolytes complexed with different lithium salts," Journal of Power Sources, vol. 180, no. 2, pp. 880-883, 2008.

[17] M. Imperiyka, A. Ahmad, S. A. Hanifah, and M. Y. A. Rahman, "Role of salt concentration lithium perchlorate on ionic conductivity and structural of (Glycidyl Methacrylate-co-Ethyl Methacrylate) (70/30) based on a solid polymer electrolyte," Advanced Materials Research, vol. 626, pp. 454-458, 2012.

[18] A. M. M. Ali, M. Z. A. Yahya, H. Bahron, and R. H. Y. Subban, "Electrochemical studies on polymer electrolytes based on poly(methyl methacrylate)-grafted natural rubber for lithium polymer battery," Ionics, vol. 12, no. 4-5, pp. 303-307, 2006.

[19] N. S. Mohamed, Characteristics of PVDF based polymer electrolytes and electrochemical cells [Ph.D. thesis], University of Malaya, Kuala Lumpur, Malaysia, 2004.

[20] S. Ramesh and M. F. Chai, "Conductivity, dielectric behavior and FTIR studies of high molecular weight poly(vinylchloride)lithium triflate polymer electrolytes," Materials Science and Engineering B, vol. 139, no. 2-3, pp. 240-245, 2007.

[21] P. K. Singh, B. Bhattacharya, R. M. Mehra, and H.-W. Rhee, "Plasticizer doped ionic liquid incorporated solid polymer electrolytes for photovoltaic application," Current Applied Physics, vol. 11, no. 3, pp. 616-619, 2011.

[22] Y. Wang, J. Travas-Sejdic, and R. Steiner, "Polymer gel electrolyte supported with microporous polyolefin membranes for lithium ion polymer battery," Solid State Ionics, vol. 148, no. 3-4, pp. 443-449, 2002.

[23] S. Ibrahim, S. M. M. Yasin, N. M. Nee, R. Ahmad, and M. R. Johan, "Conductivity, thermal and infrared studies on plasticized polymer electrolytes with carbon nanotubes as filler," Journal of Non-Crystalline Solids, vol. 358, no. 2, pp. 210-216, 2012.

[24] M. F. Shukur, R. Ithnin, H. A. Illias, and M. F. Z. Kadir, "Proton conducting polymer electrolyte based on plasticized chitosanPEO blend and application in electrochemical devices," Optical Materials, vol. 35, no. 10, pp. 1834-1841, 2013.
[25] Z. Osman and A. K. Arof, "FTIR studies of chitosan acetate based polymer electrolytes," Electrochimica Acta, vol. 48, no. 8, pp. 993-999, 2003.

[26] M. F. Z. Kadir, Z. Aspanut, S. R. Majid, and A. K. Arof, "FTIR studies of plasticized poly(vinyl alcohol)-chitosan blend doped with $\mathrm{NH}_{4} \mathrm{NO}_{3}$ polymer electrolyte membrane," Spectrochimica Acta A: Molecular and Biomolecular Spectroscopy, vol. 78, no. 3, pp. 1068-1074, 2011.

[27] Z. Yu, H. Li, K. Li et al., "A series of LiI/acetamide phase transition electrolytes and their applications in dye-sensitized solar cells," Electrochimica Acta, vol. 55, no. 3, pp. 895-902, 2010.

[28] M. J. Smith, M. M. Silva, S. Cerqueira, and J. R. MacCallum, "Preparation and characterization of a lithium ion conducting electrolyte based on poly(trimethylene carbonate)," Solid State Ionics, vol. 140, no. 3-4, pp. 345-351, 2001.

[29] M. Imperiyka, M. Ahmad, S. A. Hanifah, M. Y. A. Rahman, and N. S. Mohamed, "Investigation of plasticized UV-curable glycidyl methacrylate based solid polymer electrolyte for photoelectrochemical cell (PEC) application," International Journal of Hydrogen Energy, vol. 39, no. 6, pp. 3018-3024, 2013.

[30] B. C. Ng, H. Y. Wong, K. W. Chew, and Z. Osman, "Development and characterization of Poly- $\varepsilon$-caprolactone-based polymer electrolyte for lithium rechargeable battery," International Journal of Electrochemical Science, vol. 6, no. 9, pp. 4355-4364, 2011.

[31] A. Ahmad, K. B. Isa, and Z. Osman, "Conductivity and structural studies of plasticized polyacrylonitrile (PAN)-lithium triflate polymer electrolyte films," Sains Malaysiana, vol. 40, no. 7, pp. 691-694, 2011.

[32] S. Rajendran, V. S. Bama, and M. R. Prabhu, "Effect of lithium salt concentration in PVAc/PMMA-based gel polymer electrolytes," Ionics, vol. 16, no. 1, pp. 27-32, 2010.

[33] S. Rajendran, M. Sivakumar, and R. Subadevi, "Investigations on the effect of various plasticizers in PVA-PMMA solid polymer blend electrolytes," Materials Letters, vol. 58, no. 5, pp. 641-649, 2004.

[34] Y. Liao, C. Sunb, S. Hu, and W. Li, "Anti-thermal shrinkage nanoparticles/polymer and ionic liquid based gel polymer electrolyte for lithium ion battery," Electrochimica Acta, vol. 89, pp. 461-468, 2013.

[35] J. Y. Song, Y. Y. Wang, and C. C. Wan, "Review of gel-type polymer electrolytes for lithium-ion batteries," Journal of Power Sources, vol. 77, no. 2, pp. 183-197, 1999. 

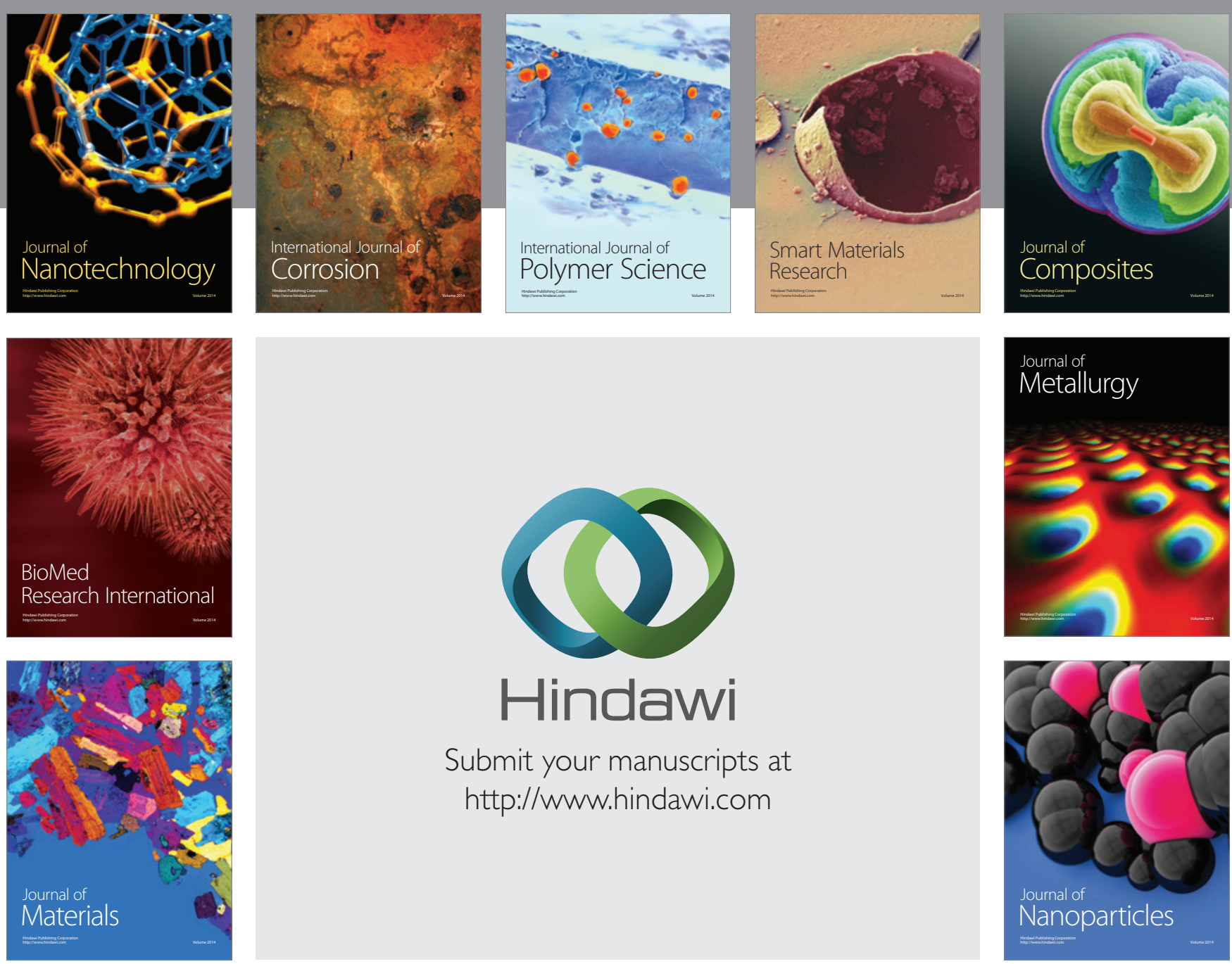

Submit your manuscripts at http://www.hindawi.com
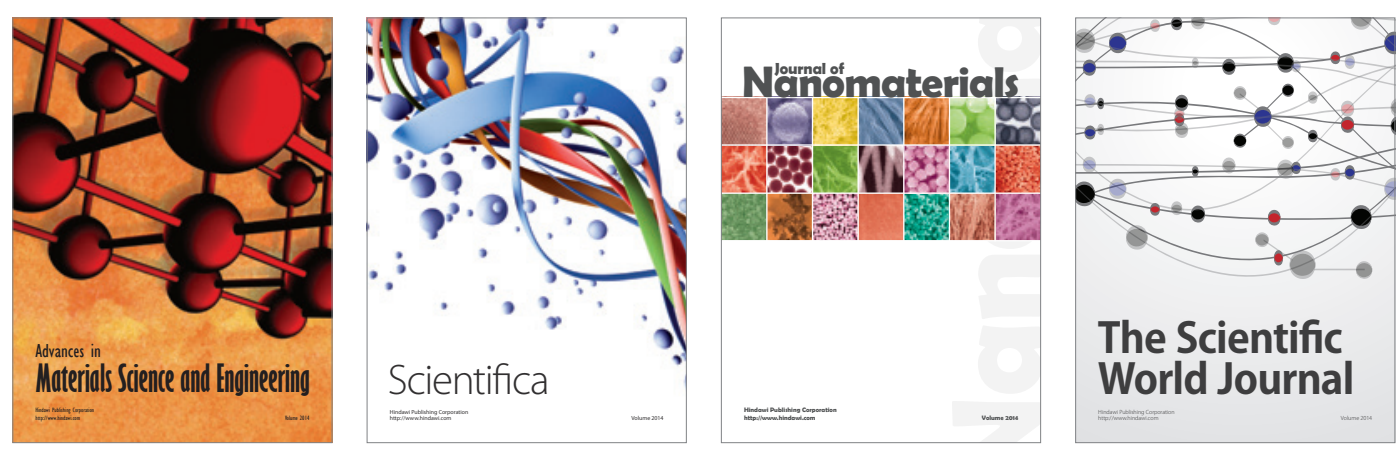

\section{The Scientific World Journal}
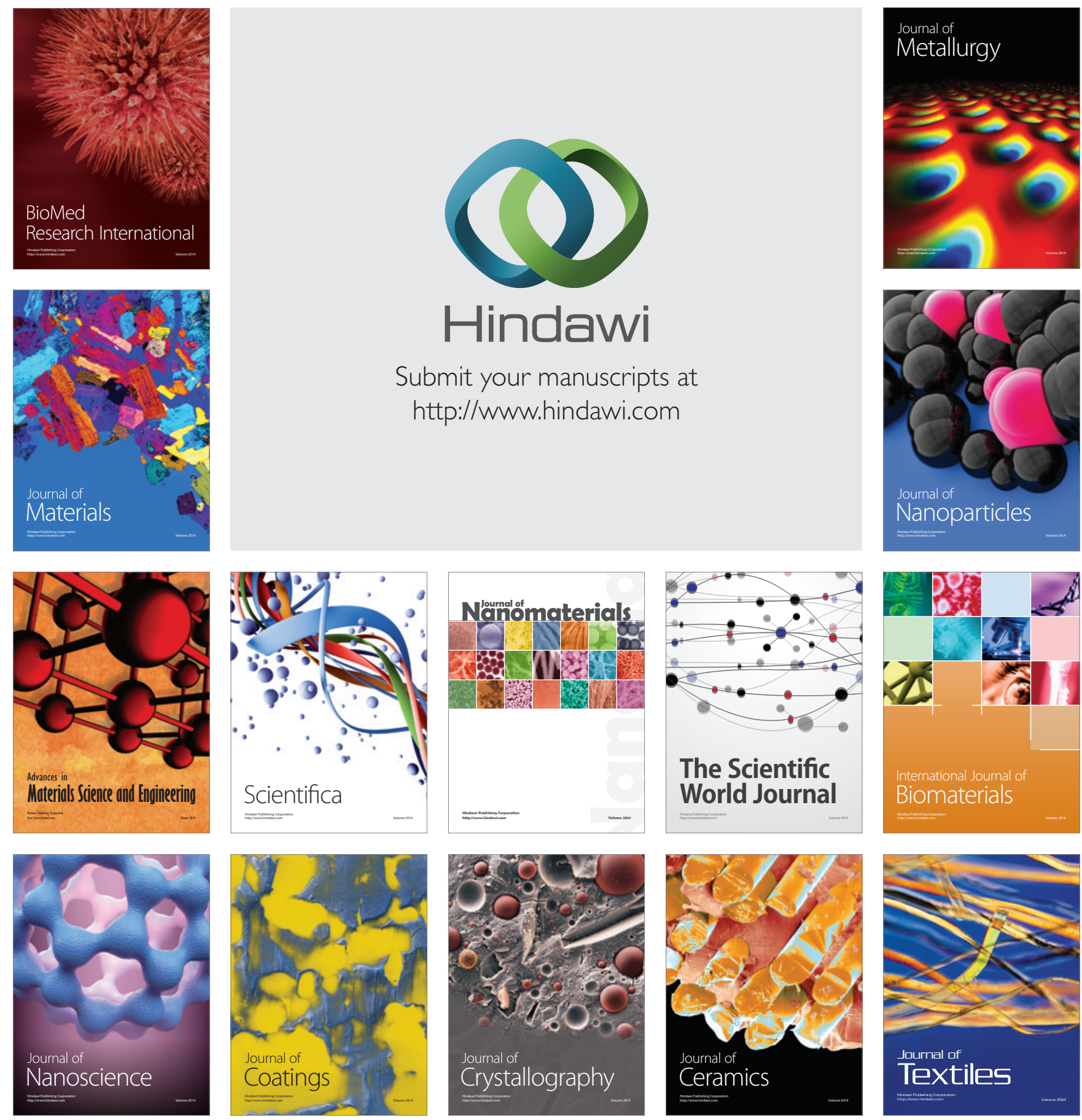